European journal of American studies

16-1 | 2021

Spring 2021

\title{
Four Japanese in Search of Henry Miller
}

\section{Wayne E. Arnold}

\section{OpenEdition}

\section{Journals}

\section{Electronic version}

URL: https://journals.openedition.org/ejas/16658

DOI: 10.4000/ejas.16658

ISSN: 1991-9336

\section{Publisher}

European Association for American Studies

\section{Electronic reference}

Wayne E. Arnold, "Four Japanese in Search of Henry Miller", European journal of American studies [Online], 16-1 | 2021, Online since 27 April 2021, connection on 08 July 2021. URL: http:// journals.openedition.org/ejas/16658; DOl: https://doi.org/10.4000/ejas. 16658

This text was automatically generated on 8 July 2021.

Creative Commons License 


\title{
Four Japanese in Search of Henry Miller $^{1}$
}

\author{
Wayne E. Arnold
}

\section{Introduction}

1 The oriental allure throughout the 19th and early 20th centuries did not escape Henry Miller (1891-1980). Born and raised in New York City, Miller resided in the epicenter of Eastern fascination in the United States. Japonisme (the influence of Japanese art on western artists) and the Madame Butterfly effect were pervasive across New York City during Miller's formative period. Having read Pierre Loti's 1887 story of Madame Chrysanthème, Miller formed images and ideas of Japan that were carryovers from the intense periods of Japonisme in the latter 1800s, but his conceptions exemplify "the craze [that] lingered on in the form of popular, intrigued curiosity about Japan" (Rij 56). Throughout his writing, references to Japan are present-even in his early publications. For reasons that will be revealed in this article, from 1955 onward allusions to Japan would conspicuously surface in more significant and detailed quantity. To be sure, it is not as though Japan suddenly reemerged into his thought and mindset: his correspondences from the 1920s and 1930s contain varying degrees of references to Japan. What changes in the 1950s is that Miller suddenly became sought after by Japan-it was a reversal of interest, or better yet, a mutual appreciation that occurred through a series of significant events that helped shape Miller's reputation in Japan. Banned in his own country until the climactic Supreme Court ruling in June 1964, as early as 1953 Miller witnessed his gradual rise to fame in Japan where he would become a celebrated author and watercolorist. ${ }^{2}$ This midcentury interest by the Japanese generated a noticeable shift in Miller's eastward focus; additionally, Miller's popularity in Japan is indicative of the Japanese-American post-war engagement. Following a watercolor exhibit in Tokyo during 1955, coupled with translations of Miller's publications, various Japanese individuals were spurred to learn about the provocative author. While numerous Japanese fans wrote to Miller, four specific men engaged in personal investment concerning the American, ultimately assisting the rise 
of Miller's national fame within Japan. The aim of this article is to reveal the previously unknown and intricate narratives concerning these four Japanese men and Miller, demonstrating the important link between an author and the advocates advancing the author's reputation, particularly in a foreign environment.

2 Technically, the earliest Miller novels published in Japan were illegal both in terms of the copyrights and in breaking of Japanese laws that prevented the publication of pornographic materials. Since these texts would influence the four Japanese to be discussed, a brief overview of these initial translations is warranted. Miller's entry into Japan occurred over a period of three years, from 1953 to $1955 .{ }^{3}$ In the beginning stages, Sexus was initially translated in 1953 by Kiya Taro (木屋太郎) ${ }^{4}$ and published by Rogosusha (ロゴス社). This text was an expurgated version, but there was also an unexpurgated bootleg edition partially serialized in the private journal (kisho 奇書) of the Limited Editions Club Tokyo (東京限定版クラブ). In addition to the sampling in the journal, the Limited Editions Club Tokyo also privately published sixteen slim volumes of Sexus, translated by Kiya Taro, which the club mailed to subscribing members. Also in 1953, Shinchosha Publishers (新潮社) would release Tropic of Cancer (1934), translated by Ōkubo Yasuo (大久保康雄), and Black Spring (1936), translated by Yoshida Kenichi (吉田健一). Shortly thereafter, more publicly available complete English versions of Tropic of Cancer, Black Spring, Tropic of Capricorn (1938), The World of Sex (1940), and Plexus (1952) would be released. ${ }^{5}$ For several years, these English editions would be highly sought after, especially when copies printed by the Obelisk Press in Paris were out of stock. While Sexus was the inaugural Japanese translation of Miller, it remained underground until a publicly available Japanese/English versionwith the content deemed pornographic printed in English-was published on Christmas day, 1954 (Rikukawa, Nihon Ni Okeru 3-4). Despite the effort by the publisher to use English to disguise certain sections of Miller's text, this edition was confiscated by the police in March 1955. After the court ruled in favor of Miller's literary merit, Sexus was translated anew by Taniguchi Touru (谷口徹) and published in its entirety in a twovolume edition in 1955 and 1956, followed by a single volume edition in late 1956.

Nearly a decade before the United States would address the issues of pornography in his texts, Japan deemed Miller's prose to be of literary merit. While seemingly mundane, the flurry of publications in the mid-1950s by Japanese publishers-both legal and illegal-contextualizes the backdrop through which Miller gradually rose to fame across Japan. The publication of Sexus brought Miller to the status of a minor celebrity, bolstered by the press received from the Japanese court cases involving his seemingly obscene books. Yet, the Japanese edition of Sexus would be the only major novel to garner attention in Japan until the Supreme Court case in the United States made international news in the 1960s. Nevertheless, these first publications were important for establishing Miller's presence in Japan. Along with the press attention from the obscenity trials, Miller's watercolors also gained notice. As early as 1955, articles began appearing that focused solely on his paintings, and he became endeared in Japan for both his literature and watercolors. Certainly, Miller's fame in Japan, just as in the United States, grew exponentially due to the media storm surrounding the legal battles, but there were plenty of readers who found something emancipating in his work. A few years ago, I received a letter from a Japanese artist who had read much of Miller's work when it was first published. He describes Miller's impact, and in doing so shines a light on why his literature was so alluring in Japan's post-war environment: 
"He was a star in the sky, a sage on the ground and a leader of life who freed us from tradition, convention, culture, and the history of a small and closed island, stirring a spirit of freedom." ${ }^{6}$ Miller, evidently, was a voice that spoke to many young Japanese who were coming of age, directionless, and lost in disillusionment after the Second World War, reluctantly watching the Americanization of Japan.

4 A significant point to bear in mind is that Miller never traveled to Japan. He made three attempts, even procuring airplane tickets; he did not depart, and Japan remained a land of intrigue for Miller. There are legitimate reasons why the trips failed to materialize, and then there are more romantic ideas that prevented his departure. With his rising notoriety, Miller planned his first trip to Japan in January of 1960 but was dissuaded by nearly everyone due to his dread of cold weather. After marrying Hoki Tokuda, he planned two additional trips only to be warned by his astrologer not to board the plane for the first trip, and for the second he was hampered by health issues that would have made the trip unbearable. For these later trips, the reality of culture shock was likely a deterrent, as even his beloved France was becoming intolerable. In my opinion, Miller allowed these travel efforts to be quickly abandoned since visiting Japan would potentially destroy the grandiose image of the country and culture that he had been building since his youth. Miller grew up in New York City, the Asian epicenter of the United States, and he would have found himself exposed to a variety of Eastern influences. In Book of Friends (1976), he attributes the dawning of his interest in Japan to his friend Joe O'Reagan, who wowed Miller with stories of Japanese women when he was in his early 20s (Miller, Book of Friends 83). Written a few years before his death, the story is almost certainly embellished to match his firmly entrenched "everything Japanese" image, but it does give us a potential reference point for the beginning of Miller's fascination with the "Orient." Throughout even his earliest literature, posthumously published, as well as his massive compendium of correspondences, references to Japan appear. In his watercolors, Miller would also occasionally incorporate Japanese themes. This all to say, by the time Japan developed an interest in Miller, Miller had long been interested in Japan.

5 As his literary fame grew, it bolstered efforts for Miller's initial watercolor exhibit in Japan during June 1955, at the Bridgestone Museum of Art in Kyobashi, Tokyo. It was at this exhibit that Kubo Sadajiro (久保貞次郎, 1909-1996) was exposed to Miller's artwork. An art dealer and educator, Kubo was struck by Miller's forms of expression through watercolor. After viewing and then purchasing some of Miller's art, Kubo contacted the artist, beginning Miller's first of several lengthy correspondences with various Japanese. In what follows, I present previously unknown historical details concerning Miller and Japan; on the basis of archival materials, letters uncovered during field research in Japan, and personal interviews, I examine in the ensuing sections four unique individuals who sought to better understand Miller's artistic message. Three of these men, Kubo Sadajiro, Ueno Shōri (上野霄里, b. 1931), and Tobita Shigeo (飛田茂雄, 1927-2002) would engage Miller in correspondence. The fourth, Honda Yasunori (本田康典, b. 1938), an academic, has risen to become one of the foremost Miller scholars in the world. While I look at these individuals in four separate sections, it should be understood that they were all mutual friends, to some degree or other. Each man left a significant impact on Miller's Japanese reputation and status, derived from their desire to promote the author's legacy. The men who interacted with Miller also provided him with desired information about Japan-cultural information but also information about Miller's spreading reputation. There was a valuable 
exchange occurring, one that provided both parties with something of worth. Essentially, Miller chose to engage with Japanese who could enlighten him about the mystique of Japan. As we will see, however, Miller occasionally drifted into Americentrism, which limited his ability to fully grasp the gulf between the East and West.

6 Most often referenced by Miller's biographers is his 1967 marriage to Hoki Tokuda (木 キ徳田, b. 1937), nearly fifty years his junior; however, Miller's association with Japan has been largely overlooked in both academic contexts and biographical studies. Miller's longest foray into things Japanese, Reflections on the Death of Mishima (1971), came well after his established fame in the country. A self-reflecting text stimulated by the death of Mishima Yukio (三島由紀夫, 1925-1970), the epistle was serialized in Japanese in the Shuukan Post (週刊ポスト) during the fall of $1971 .{ }^{7}$ Caroline Blinder's study on Miller, A Self-Made Surrealist (2000), includes an extensive examination of Reflections, but does not address Miller's personal connections to Japan. The only English article to discuss at length Miller's fascinations with Japan is Katrin Burtschell's "Anaïs Nin, Henry Miller, and Japan-An endless fascination," published in A Café in Space: The Anaïs Nin Literary Journal, in 2005. Burtschell is primarily concerned with Miller's interest in Japan as represented through his literature and published letters, with a specific focus on his life in New York City in the 1920s and then in Paris during the 1930s (see Burtschell). Elsewhere, Harry Kiakis, in Henry Miller in Pacific Palisades (2017), recounts several conversations in Miller's home during the late 1960s, supporting an argument that Miller surrounded himself with an "oriental" atmosphere beyond just being married to Hoki Tokuda (see Kiakis). Several years after Miller's death, the formation of the Henry Miller Society of Japan by Kubo Sadajiro, in 1986, led to the publication of eight volumes of The Bulletin of the Henry Miller Society of Japan, followed by Delta: Studies on Henry Miller, Anaïs Nin and Lawrence Durrell, now in its eleventh volume. The vast majority of this research focusses on Miller's literary output; however, there are a few pieces addressing Miller and Japan. The articles on this subject invariably surround the four men discussed below, but these fail to interact directly with the background details between each man and Miller-specifically since up until now, the private correspondences have been left largely untouched in archive collections within the United States and Japan. Additionally, through field research in Japan, I have located Miller's original letters to two of these men, providing an enlightening look at the Japanese-American dialogue within this group of authors. In the sections that follow, I also engage with previously untranslated Japanese materials to extrapolate the larger significance of Miller and Japan, revealing an empirical correlation between the two, warranting further examination that will advance our understanding of the richness and diversity in the post-war link between the two countries.

\section{Kubo Sadajiro: Art Dealer}

7 First reading Miller's literature in 1953, Kubo Sadajiro was not greatly impressed. Nonetheless, Kubo became the most significant publicist and distributor of Miller's watercolors in the world, through his printing company, and he reproduced Miller's works of art as lithographs and distributed them across Japan, eventually reaching a global market. Writing Miller in 1956, Kubo recalled that, “3-4 years ago I discovered 
your name as the author of Sexus. The Japanese translation of Sexus was printed in [a] thin booklet by [a] secret edition of an obscure publisher. I read it without attention and could not understand the pages and felt rather unpleasant." ${ }^{8}$ The pamphlets to which Kubo refers were the slim bootleg prints published by Limited Editions Club Tokyo. In later years, when reflecting on his introduction to Miller, Kubo elaborated: "at some point during reading Sexus, I became overwhelmed by the depressing depictions, and was unable to finish reading" (Bijütsu 69-70). After his introduction to Miller, in June 1955 Kubo attended the exhibit of Miller's watercolors held at the Bridgestone Museum of Art. Recounting his visit, Kubo wrote:

The exhibit took place from June 9th to the 26th, and I visited the venue together with Ei-Q on one of those days. When we entered the display room, we were immediately captivated by free, lighthearted, bright watercolors. Miller's paintings were unfussy, like those of children. Within them honesty, boldness, and dreams lost in current times bloomed like so many flowers. (qtd. in Usuda 5-6) ${ }^{9}$

Impressed with Miller's watercolors, Kubo purchased three pieces. On a subsequent visit to the exhibit, he recalls running into the eminent French art critic Fukushima Shigetaro (福島繁太郎, 1895-1960), who allegedly asserted within earshot of Kubo, that, "Miller is an amateur who has no form of his own" (Kubo, "Gifted Painter" 100). In complete disagreement with Fukushima, Kubo's interest in Miller continued to grow along with his desire to contact Miller; yet, it took almost a year to learn Miller's address in Big Sur, California. Once obtained, Kubo mailed a package, surprising Miller with a gift of brushes and watercolor supplies. No note was included with the materials, so using the return address Miller dispatched a short enquiry: "Dear sir: I received a gift package of paints and brushes recently but do not know whom to thank for it. Can you tell me?"10 That Kubo and Miller would initially exchange mail specifically dealing with watercolors is predictive of their future partnership together. Over the next several decades, Kubo avidly sought to acquire original Miller watercolors and would eventually print thousands of lithographs, bringing Miller's artwork to the attention of millions of viewers throughout the world.

9 Sharing creative interests was essential in bonding the friendship of Kubo and Miller, yet their interaction was not limited to buying and selling watercolors. Kubo, though not an avid reader, was a collector of books. Throughout the years, Miller readily provided him with missing or new books for his collection; in return, Kubo shipped Miller artbooks covering a variety of Japanese styles. Isolated as Miller was in Big Sur, Kubo's missives were welcomed as a new and exciting connection with the mysterious eastern land. At one point in early 1957, Kubo gifted Miller with a book containing prints of Japanese women; yet, the more contemporary the art, the more Miller expressed his disdain of Western influence creeping into the Japanese artistry. "Incidentally," he wrote, "how poor are the modern paintings in this book-toward the end! You people have little to learn from the West. It is we who need your instruction, your way of looking at life." ${ }^{11}$ While Miller lamented this Western shift, in contrast, the effects of Japonisme would play a significant factor in his personal life; across decades of his written and painted material, references to Japanese art and literature appear in various forms. After Miller mused to Kubo about the writing style in the Japanese novel Homecoming (掃拫, 1955), by Osaragi Jiro (大佛次郎, 1897-1973), ${ }^{12}$ on his next trip to Tokyo, Kubo procured four additional Japanese novels printed in English and shipped them to Miller. ${ }^{13}$ Through Kubo's assistance, Miller began receiving more material from Japan than previously accessible. As a result, his enthusiasm for Japan rapidly 
expanded, and he professed to Kubo, "I could write pages and pages about my feeling for Japan." ${ }^{14}$ This interest also meant that further references to Japan were appearing in Miller's publications.

10 Discovering that Kubo had accumulated a large collection of his original watercolors, in 1967 Miller began to discuss with Kubo the possibility of another watercolor exhibit in Japan. Miller had been reading a translation of an article by Ikeda Masuo (池田満寿 夫, 1934-1997), entitled “Henry Miller and 'Henry,"” published in the February issue of Literary Arts (Bungei, 文芸). Ikeda had recently won the International Grand Prix for his prints at the 33rd Venice Biennale, in 1966. In his first of many articles on Miller, Ikeda discussed his fascination with Miller's watercolors and mentioned in passing Kubo's trove of originals. When Miller learned of Kubo's collection, he wrote expressing his surprise:

As far as I can make out you must have about 32 or 33 watercolors, yes? You mention another 25 from the Bridgestone Gallery exhibition in 1957. Are these watercolors, and do you also possess them? This would make quite a big collection. With those owned by other collectors in Japan, which you say you could trace, there are already enough for another showing and two or three albums $!^{15}$

The peak period of Miller's watercolor fame came during the beginning stages of his illfated fifth marriage to Hoki Tokuda. Due to his exploding popularity, by April 1968 an exhibit of 90 watercolors was arranged for two weeks in Shinjuku, Tokyo. Consequently, Kubo's family wealth allowed him to pursue his interest in art criticism; an avid traveler from a young age, he had gradually acquired Miller's art that eventually allowed for the Tokyo exhibit. Miller was expected to attend, but when the airplane landed in Tokyo only Hoki disembarked. Miller canceled last minute due to (among other reasons) health concerns.

Reproducing and distributing Miller's artistic output set in motion Kubo's role in the exhibit in Tokyo. As an active patron of the arts, Kubo had continually labored to help support a variety of artists by replicating their pieces for reasonable prices. Directly linked with the artist Ei-Q (瑛九 Eikyū, 1911-1960), founder of the Democratic Artists Association (デモクラート美術家協会, Demokurāto Bijutsuka Kyōkai), Kubo provided financial support by selling reproductions of artists' products through his art seminars and at auctions. He believed that to increase interest in an artist, buyers should be able to own art reproductions, thereby creating a closer connection between the artist and audience. With his extensive background in art facsimiles, Kubo and Miller eventually figured out a system through which Kubo would send lithographs to Los Angeles to be signed by Miller and then be returned to Japan. This method, while tedious, suited both men. There were occasional issues with customs, but in most cases the prints made their way back to Japan, signed and numbered. Perhaps Miller's best-selling pieces in Japan were born out of the tribulations in his marriage with Hoki. The Insomnia watercolor series consisted of the twelve images, each turned into 200 lithographs, signed and numbered by Miller. In 1973, Kubo published a limited-edition series of his largest collections of Miller's art. By this point, Kubo was publishing not only Miller's artwork as stone-plate lithographs, but also as silkscreen prints and etchings (Koeppel 8). Miller and Kubo continued their arrangement of lithograph exchange across the ocean until 1980, when Miller's health would prevent further engagement with the scheme.

Though Kubo was not keen on Miller's sexual depictions, he was, nevertheless, enthralled with Miller's expressions through the medium of watercolor. Therefore, 
during Miller's life, and particularly after, Kubo prolifically wrote about his watercolors. As early as 1960, Kubo began publishing articles in an effort to bring attention to the lesser-known side of Miller's artistry. Many of these articles were gathered in Volume 8 of Kubo's collected writings, The World of Art: Henry Miller (1984). With his art criticism and watercolor reproduction, Kubo played a critical role in spreading Miller's art across Japan. In Kubo's initial letter to Miller in 1956, he conveyed his attraction to the pieces: "How much I was enchanted by your pictures! That frankness. That being free!" ${ }^{16} \mathrm{He}$ also found the allure of Miller's pieces linked to its child-like quality. Ever since a North America and Europe trip in 1938, Kubo had been enamored with paintings produced by children. When he returned to Japan, he strove to provide opportunities for children to learn painting, even going so far as to establish a children's art competition, and he eventually engaged in research and the promotion of art education in Japan (Usuda 3-4). In this light, Kubo felt that Miller's paintings came close to those of children, but ultimately, he believed there was something more profound in his art.

Intent on supporting Miller studies in Japan, after Miller's death Kubo formed the Henry Miller Society of Japan, in November 1985. Initially, it was a small group of Japanese individuals interested in Miller. In April 1986, with eighteen members, the society published a collection of essays in The Bulletin of The Henry Miller Society of Japan. At a mere 32 pages, the publication was a modest affair, with Kubo serving as president of the society. In the beginning of the 1990s, Miller's name was again receiving fresh attention with a bevy of new worldwide publications in tandem with the release of Philip Kaufman's film, Henry \& June (1990). Miller's centennial saw the releases of new biographies, evaluations, reminiscences, and the release of original Miller manuscripts previously unknown. These events attracted people in Japan and the Miller Society burgeoned to more than eighty-five members by 1991 . The sixth bulletin, published in 1991, reached 151 pages and twelve contributors, including Jay Martin (in translation), author of Always Merry and Bright: The Life of Henry Miller: An Unauthorized Biography (1978). The flurry of interest in Miller was not lost on Kubo, and he wrote in the introduction to the sixth volume, "major authors like Miller make waves every hundred years or so, and it's vital that we continue researching and exploring him. It will probably take another 500 years for this boom to end" ("Toshinose" $3-4$ ). While the Miller society continued to grow in terms of membership, peaking at more than 110 members in 1993, scholarly contributions eventually declined, and The Bulletin of The Henry Miller Society of Japan ceased publication with the eighth volume. Yearly meetings were held throughout the 1990s, but it would not be until 1998 that DELTA: Studies on Henry Miller, Anaïs Nin and Lawrence Durrell would become the new journal for the society.

Constantly revolving around watercolors, Miller and Kubo's professional association thrived due to Kubo's perpetual interest in learning about Miller. He eventually met the artist in Los Angeles in 1967 and 1970. These were short visits, but they helped form an intimate bond between the two men. One driving force behind their meeting was that Kubo wanted to see firsthand Miller's painting studio. ${ }^{17} \mathrm{~A}$ friend once described Kubo's life as an art critic becoming tangentially aligned with that of an artist:

for Kubo, a man who could swiftly put his ideas into action, it must have been difficult for him to imagine how artists could be periodically stumped. Having been so immersed in Miller's world, however, Mr. Kubo, probably felt now more than 
ever the elements of passivity and loneliness and emptiness that come with being an art critic and collector. (Tokuda 16)

In addition to founding the Henry Miller Society of Japan, Kubo was able to acquire thousands of original letters from Miller to Bezalel Schatz, Kathryn Winslow, Sava Nepus, and Hoki Tokuda, as well as several manuscript drafts. Following Kubo's death in 1996, the Kubo Memorial Tourism and Culture Exchange Center (久保記念観光文化 交流館) was established at his family property in Mooka City, Tochigi Prefecture. Composed of several buildings, the complex houses Miller's letters and watercolors in a traditional Japanese storehouse that is now converted into a museum dedicated to Kubo. The Kubo Memorial regularly exhibits Miller's watercolors, thereby continuing his passion for Miller's artwork.

\section{Ueno Shōri: Japanese Author and Philosopher}

17 Similar to Kubo Sadajiro's initial contact, Miller unexpectedly received his first letter from Ueno Shōri. The outcome would turn into a camaraderie that lasted fifteen years, from January 1965 until Miller's death, and resulted in nearly 400 letters being exchanged..$^{18}$ Unlike Kubo, however, Ueno was almost entirely focused on Miller's literary messages, having read the Japanese publication of Nexus in 1963. During the early 1960s, Ueno transformed himself from Christian ministry into a scholar, allowing himself the freedom to seek out a new life and, in some respects, follow in the footsteps of Miller while also retaining his own unique Japanese identity. Ueno evolved into a philosopher of life and believed in an artistry that rejected labels such as "author" and "philosopher." As such, he pursued a literary friendship with Miller as a form of guidance, once stating that Miller's writings were, in his opinion, second only to that of the Bible. He described Miller's texts as "blood bubbling writing," and professed that Miller created "negative love in his books and positive love in his water colorings." ${ }^{19}$ Having previously struggled in his life as a minister, Ueno found a new passion in Miller's writing, one that facilitated the revival of his energies within his perceived stifling Japanese society. Miller's negative love was a form of chastisement against society, a harsh wakeup call, Ueno believed; yet, Miller's watercolors perpetrated a softness, a gentleness that gave birth to positivity. In Ueno's letters, he expresses unending gratitude concerning his association with Miller, as their epistolary connection brought him rejuvenation. Interestingly, there was an unintended outcome for Ueno that ultimately benefitted his literary career. As the missives grew in number, Ueno would become known in Japan as having an extensive collection of letters from Miller. This association, in turn, would help disseminate Ueno's name and writings across Japan.

18 Occasionally beginning his greetings with "My dear Master," Ueno, ardent admirer of Miller, unreservedly demonstrated his devotion for his American guru. Ueno's enthusiasm offers a unique view of a Japanese interpretation of Miller's philosophy. The depth of their involvement also illustrates that Miller was not merely speaking to the western man. His ideas were valuable for Japanese society, Ueno believed, if the people would merely approach his literature for something other than just pornography. Ueno intimated that he was the man from the Orient that Miller was destined to meet, as predicted by a soothsayer during Miller's journey through Greece in 1939. "A Greek prophet predicted Miller and my meeting close to 40 years ago" 
("Henrī Mirā" 180), Ueno wrote in 1978. Miller had revealed the fortune teller's prophecy in The Colossus of Maroussi (1941), wherein he claimed that it had been predicted that "I would make three trips to the Orient where, among other things, I would meet a man who would understand me as no one had and that this meeting was absolutely indispensable for the both of us" (Colossus 194). Through their friendship and then a single meeting on September 16, 1977, at Miller's Los Angeles home in Pacific Palisades, Ueno believed that their bond was preordained. Immediately after their meeting, he wrote Miller about his overwhelming feelings: "What a blessed day I have had, chez toi! I really wept. At first when I met you, I could not utter a word due to my heart's weeping. What a mild and peaceful man you are! .... You are my father; my spirit will be lifted whenever your name is mentioned! ${ }^{20}$ The impact of physically meeting Miller after such a long period of writing each other left an indelible impression on Ueno; almost forty years later, when I visited his home, he vividly recalled the impact of that moment with Miller.

Very much under Miller's literary influence, Ueno's transition away from Christian ministry to writer and philosopher flowed into his words. Early in their correspondence, Ueno professed, "I have made up my mind to write the truth according to my own heart, not the superficial story, which so many authors intend to write, [but that] which I have been desiring to write for a long time. Now, every one of your words awaken the eye of my soul against the real life!" ${ }^{21}$ Religious elements of Ueno's past remained present in his writing, and his epistles to Miller often carry a confessional, disciple-like tone. In his first year of writing, Ueno would fill numerous pages with admiration, explaining how reading Miller was altering his perception of both Japan and the cosmos. Referring to Miller's oeuvre as a macrocosm in and of itself, Ueno rhapsodized, "I am now standing like a diligent astronomer facing against the universe over his head .... I, as an astronomer, heard you through your books and your very own handwriting .... Being a universe, you cannot be defined by any man-made definitions. This state itself is the true authority among all existence."22 Ueno could be classified as one of Miller's more eccentric readers and with Miller's increasing literary fame, he knowingly attracted a more unconventional assortment of devotees, as one critic mused in 1965-the same year Ueno penned his initial letter-"the epigones, and their ever more oddly contracted sympathies, join with Miller. They find him, that is, at perigee, and descend from there" (Capouya 87). While retaining his distinct Japanese personae, this devotion to Miller would ultimately direct Ueno's writing, and his level of commitment to his own writing struck Miller as something entirely Japanese. Replying to another one of Ueno's adorations, Miller wrote, "when you say things like this, I think you are as a true Samurai, afraid of nothing. And also, a genuine 'fanatic'. (Like myself, like Hitler, like Gandhi, like Attila the Hun)." ${ }^{23}$ Forty years Ueno's elder, Miller would caution him to not lose control of himself, that one must have balance. "Sometimes I think you are trying to do too much," Miller admonished, "I know that you have had a great release of powers, as if some magician had touched one of the potent chakras along your spine. One must be careful in such cases. A man is not a dynamo. He must be able to control these wonder-working powers, and not let them overpower him, destroy him." ${ }^{24}$ Some of Ueno's prolific writing included articles about Miller. Spurred on during their fifteen-year association, the strong union between the two men even led to making yearly phone calls on Miller's birthday. For Miller, however, Ueno served as a critical observer of Japan, a person he could receive frank and (presumably) accurate descriptions of everyday Japanese life in the 1960s. 
20 Miller had yet to meet Hoki Tokuda when Ueno sent his initial greeting on January 6, 1965, and Miller's span of interaction with Japan was considerably narrower than it would be by 1968 . While Ueno often described his daily life with his wife and three boys, he also provided a social viewpoint of Japan that was firsthand as well as critical. Very much in line with Miller's The Air-Conditioned Nightmare (1945)-a biting criticism against American culture and society-Ueno's content regularly portrays a negative perception of Japan, referring to it as "the dead country on the other side of the Pacific," 25 where he felt surrounded by "sleeping Japanese." ${ }^{26}$ From Miller's perspective, Japan was alluring and vibrant, and he found himself continually drawn to Japanese women. When he met Hoki Tokuda in 1966, his communication with Ueno began including discussion of relationships with Japanese women. Yet, Miller quickly found his infatuation with Hoki causing more pain than enjoyment, and he often asked Ueno for advice. Furthermore, Miller noted his confusion with Japanese men and women as he began interacting with them at the Imperial Gardens, a Japanese restaurant and music lounge on Sunset Boulevard, where Hoki played piano. At one point, Miller wrote, "I am beginning now to agree with you, that at bottom your people are a melancholy people." ${ }^{27}$ For the most part, Miller remained optimistic, even idealistic about Japanese culture and society, and along with Ueno, he lamented the Western influence within Japan.

21 Obviously benefitting his own professional endeavors, Ueno self-initiated his association with Miller. This is not to say that Ueno depended on Miller to establish his writing career; rather, Ueno expressed his admiration and acknowledged Miller's impact on his life, and in turn, Miller offered to aid his early literary efforts. Two of Ueno's most well-received publications are Single Cell Thought (1969, 単細胞的思考) and Tropiques en Voyageur (1972, 放浪の回帰線), in which Miller is at the center of the discussion. Ueno secured an introduction from Miller for the first book and an introduction for the second, mostly focusing on Miller, by J. Rives Childs, a long-time correspondent with Miller. In a postscript to the second book, Honda Yasunori (discussed below), underlines the connection he sees between Miller and Ueno's writing: "I want to stress that, when examined closely, Ueno is Miller's ideal reader, and Miller is Ueno's ideal writer. Thus, Tropiques en Voyageur is a discussion of Miller written by the ideal Miller reader" ("Hōrō No" 543-44). Additionally, over the decades Ueno wrote hundreds of short essays, many of which are republished in Collected Essays (2015, 幽篁記). In Tropiques en Voyageur, Ueno clarifies the interest in his American friend: "I am strongly attracted to Miller not as a literary figure, not to Miller as a thinker, but to Miller as a human being, with the various body odors that characterize a healthy human being" (Tropiques 545). Ueno ignores Miller's American cultural identity, emphasizing rather the human connection. Miller, however, very much associated Ueno with the Japanese traditions, especially in his introduction to Single Cell Thought: "in some ways Ueno-San reminds me of those reformed, or better, enlightened samurai we see in Japanese films-I mean samurai who have abandoned the sword out of disgust with senseless killing and who endeavor to live like simple, almost foolish individuals." ${ }^{28}$ While they focused on different elements in each other-Miller was limited to the correspondence, being unable to read Ueno's Japanese publicationstheir mutual respect arguably makes Ueno the most trusted of Miller's Japanese friends. 
The exchange of mail with Miller occasionally brought Ueno national attention. The name association with Miller during the latter 1960s and early 1970s helped Ueno reach a larger Japanese audience but did not propel him to fame. In 1970, Ueno was featured alongside Miller and Hoki in a Weekly Playboy [週刊プレイボーイ] article that specifically attributed Ueno's assistance in helping Miller through his insomnia caused by his troubles with Hoki. The article undoubtedly exaggerates the claim that "by painting watercolors and writing long letters to Ueno, he was just able to make it through these long, sleepless nights" ("Kakitsuzuketa" 30). Also included in the article is a reference to the extensive written dialogue between the two men, albeit also aggrandized by the magazine. Years later, Ueno would be featured in Women's Weekly [週刊女性]. Based in part on their correspondence, the article leader read, "Henry Miller and other world-famous cultured people praise him as Japan's prominent philosopher" ("Tōhoku" 58). Such appearances linked Ueno's writing with Miller's Japanese popularity, thereby suggesting an international correlation surrounding the two writers. These associations implied that the Ueno-Miller connection had created a mutually codependent friendship, with each writer gaining something from the other in their quest for understanding. The passion with which Ueno embraced Miller flowed into his writing, and various Japanese readers captivated by Miller gradually found their way to Ueno's publications.

\section{Tobita Shigeo: Translator and Literary Critic}

Initiated by Tobita Shigeo's desire to accurately translate Miller's message for Japanese readers, the correspondence between Miller and Tobita spans less than two years, from November 1971 to August $1973 .{ }^{29}$ An academic and literary critic, Tobita began writing about Miller in the mid-60s; his publications include literary analysis as well as pieces for broader audiences in newspapers and magazines. Tobita translated Miller's Remember to Remember (1947) in 1968, followed by To Paint is to Love Again (1960). He initially wrote Miller seeking input concerning difficult passages; as their correspondence grew, the letters demonstrate a growing friendship of the two men. As such, the dialogue surrounding Miller and Tobita is rich in content, with Miller providing valuable insight into his own literary works. Miller encouraged Tobita's enquiries to clarify difficult passages in his writing. Concerning the accuracy of translations, Miller told Tobita, "I would rather be bothered, disturbed by questions (from translators), than to find out later on that bad errors were made." ${ }^{30}$ During the translation of Semblance of a Devoted Past (1944), Tobita mailed Miller questions on uncertain meanings, re questing Miller's specific elucidation. Miller's responses, which he mimeographed before returning, reveal a cultural gap in that he maintained a very Western perspective of his writing, and these comments demonstrate an overarching failure to understand the vast differences involving Japan and the West. In one section, Miller wrote, "Heavens! Do you put footnotes explaining these things to your readers? So unnecessary!" ${ }^{31}$ Miller was often rather critical of the notes made by some of his translators, and Tobita was no exception. This exchange illustrates Miller's oversight to the dramatic cultural background disparities separating his western and Japanese readership. Interactions with Miller and his translators could often prove difficult, and Miller's slightly condescending attitude to Tobita's questions perhaps led to some animosity. 

had lapsed for several months while Tobita was involved with other projects. Resuming in July 1973, they brought each other up to date on the events of the year. Almost immediately, Miller revealed an idea for a Mandarin translation of the poem, "Children Learn What They Live" (1954), by Dorothy Nolte (1934-2005). The poem was popular in the 1970s and Miller had an embroidered version hanging above his ping-pong table. The translation, Miller stressed, was to be undertaken by someone with "excellent calligraphy, and do it on good paper, so that it will look like a work of art." The intended translation was for Miller's love interest, Lisa Lu (b. 1927), and he wanted secrecy concerning the project. Quickly the objectives became muddled, as Tobita understood the translation to demand a highly trained professional, whereas Miller wanted merely a gift for Lu. In his effort to find the best translator and artist, Tobita secured a Chinese man, a relative of Henry $\mathrm{Pu}$ Yi, Tobita claimed, and the translation would therefore be completed by an expert calligraphist-but it would not be cheap. After informing Miller that the professional translation would cost $\$ 200$, Miller posted a fierce reply of rejection and, in turn, inadvertently severed his relationship with Tobita. In his final letter, Tobita voiced his shock:

I just don't know how to express my painful sadness in reading your not much witty letter of August 8. Honestly, it's incredible to me that you should have dictated such fuming sentences .... I've been entertaining a gravely wrong idea of friendship, and I must beg your generous pardon for my impoliteness. The mere thought of my imprudent letters incurring the displeasure of the great writer I most admire makes me miserable, incurably miserable. ${ }^{34}$

The demise of their communication demonstrates the cultural and linguistic obstacles that appear across many of Miller's foreign interactions. Of course, such obstacles are not surprising or rare, and Tobita's reaction to Miller's diatribe over what he thought were exorbitant fees might also be expected. Ultimately, Tobita felt he had overstepped himself in seeking a better understanding of Miller, and the harsh response from Miller allowed Tobita to tactfully end their involvement.

The disappointing finish of their friendship did not completely sour Miller for Tobita. Instead, he continued writing about Miller, although he never again translated another one of his novels. Tobita was a Professor of English at Chuo University in Tokyo, and 
while Miller translations were part of his professional field, it was more a labor of love. He was also a translator of the New Testament, and in the beginning of the 1970s he was occupied with a new colloquial Japanese version of the Bible-a project that would never finish, he reported to Miller-thus the reason in 1973 for his delay in writing. When Miller sent the biting response concerning the Chinese translation of the poem, he revealed a side of himself that Tobita found offensive and unfamiliar. These feelings may have left a lasting discomfort in Tobita's memory. As time passed, Tobita remained connected with Miller in Japan, and from 1994-98, he served as president of the Henry Miller Society of Japan. In his preface to the 1998 inaugural issue of DELTA: Studies on Henry Miller, Anaïs Nin and Lawrence Durrell, Tobita intentionally paraphrases Norman Mailer, observing,

the 'real Henry Miller' appears slightly different than both the Henry Miller as portrayed in his works and the Henry Miller as spoken about by close friends like Anaiis Nin. Within those slight differences may be found the entire essence of Miller's own personality, his great paradox as an artist, and his failures. ("Hakkan" 4)

29 By using Mailer as a foil, Tobita hints at his falling out with Miller, indirectly referencing the surprise he felt amidst his ideal of Miller and the Miller that was revealed in their last exchange. The paradox of Miller-the-man and Miller-the-author, especially in terms of his image in Japan, was present in Tobita's mind but did not prevent him from continuing to praise Miller's literary merit. Writing in 1971 for Miller's upcoming 80th birthday, he expressed the opinion that the American's status in Japan was being aggrandized and praised to extremes:

Readers today are able to better understand the matters concerning his liberation from the machine civilization and his achievement of self-realization, as well as his ideas of internal revolution and his intentions to boldly free himself from the tendency to make sexual nature taboo, and his works are now coming to be evaluated fairly. However, we also now find an opposite extreme in our country in which people take things too far and only view Miller as a social critic, or make him out to be a religious figure, like a part of the Beat Generation once did. ("80 Sai" 7)

Certain Japanese were placing Miller in limiting categories-social critic, or religious figure-which misconstrues Miller's ideas, Tobita suggests. It is clear that his initial interest in contacting Miller revolved around an effort to better understand Western thinking and how best to present the freedoms from everyday life that Miller professed. Overall, he remained reserved about the popular status Miller held in Japan, and decried any tendency to limit the importance of Miller's literature by pigeonholing him on a single pedestal.

\section{Honda Yasunori: Henry Miller Scholar}

31 Unlike the three previous men, Honda Yasunori never initiated a correspondence with Miller. As an academic, Honda was well aware of Miller's disdain for those with a scholarly interest in his life, and even though his initial article on Miller was published in 1968 (several years before Miller's death) Honda chose to remain distant. Honda is a scholar engaged in understanding the machinations and meaning in Miller's writing. For the last six years, Honda and I have exchanged numerous letters and met several times to discuss the historical trajectory of his research..$^{35}$ Very much in the vein of Life Writing studies, Honda melds biographical with literary analysis. Through his research, 
he sought how best to interpret Miller's writings in a manner that allows Japanese readers a broader understanding of Miller's more intricate biographical and philosophical writing. For Honda, making contact was not necessary as long as he had access to Miller's publications and archival materials scattered across the United States. Several decades of extensive research have allowed Honda to enrich his publications and make innovative advancements in Miller studies. Of course, the limiting factor for scholars outside of Japan is that all but five of Honda's fifty-plus articles and book-length studies are written in Japanese. ${ }^{36}$

The breadth of Honda's research focuses on two areas: the religious element in Miller's writing and the biographical details of his New York and Paris periods. Both areas of Miller's life have been extensively written about by scholars outside of Japan; nevertheless, Honda has uncovered numerous new avenues of exploration due to his extensive archival research. While an exhaustive overview of Honda's publications is beyond the scope of this section, a few titles provide a meaningful snapshot of his research focus; select articles include: "Theory of Jesus Christ in Henry Miller" (1977); "Lafcadio Hearn and Henry Miller" (1984); "John Cowper Powys and Henry Miller: John and Christ" (1992); "Helena P. Blavatsky and Henry Miller: The Voice of the Silence and Tropic of Capricorn" (2008); "The Appearance of a Japanese Person in Sexus: Tori Takekuchi"(2010); and the recent The Story of Tropic of Cancer: Henry Miller and his Companions (2018). Across the decades of research, Honda has dedicated himself to uncovering biographical connections between Miller and the characters in his novels, with a primary focus on Miller's life in the 1930s and 1940s. While it is unlikely that Miller knew about Honda's publications, Ueno Shōri did send some of Honda's articles to Miller's friend and avid Millerania aficionado, J. Rives Childs. ${ }^{37}$

When Honda first encountered Miller, he was attending Waseda University in Tokyo as an undergraduate student. Honda explained during one of our interviews that he stumbled across a novel by Miller at a used bookshop and, contrary to the contemporary public opinion, instead of being pornographic he found Miller's voice struggling to transcend both time and space. Honda recalls that as a graduate student at Waseda in 1962, one of the earliest academic articles he read about Miller was published in his university journal, English Literature. ${ }^{38}$ The publication featured an article entitled "Henry Miller" by a then-unknown adjunct professor, Kate Millett (1934-2017). Millett would go on to reach international acclaim in 1970 with her revolutionary arguments in second-wave feminism, published in Sexual Politics, which predominantly featured a feminist analysis of Miller's novels. A few years later, when Honda published his first article on Miller in 1968, he was working at Hirosaki Gakuin Junior College (弘前学院短期大学) in Aomori Prefecture, northern Japan. After the publication of several articles on Miller, combined with Miller's extreme popularity in Japan, he was invited in 1976 to join Miyagi Gakuin Women's University (宮城学院女子 大学), in Sendai, Japan. Here he remained until his retirement in 2006, now holding the rank of Professor Emeritus. His early interest in Miller and the research producedMiller as an image of Christ in the Twentieth Century-resulted in the occasional negative feedback, such that Honda often felt isolated in Japan with his study of Miller. Possibly Miller himself would have denounced Honda's interest in this Christocentric approach. Along the way, Honda formed friendships with the three previous men discussed in this article, Kubo, Ueno, and Tobita, and made the acquaintance with another Miller correspondent, Koga Tsutomu (古賀孜). As his reputation grew, Honda 
eventually became, and remains, the preeminent Miller scholar in Japan, a position he hesitantly admits to holding. ${ }^{39}$ In addition to his research, Honda was the president of the Henry Miller Society of Japan from 2002 to 2019, at which time he retired at the age of 81 .

34 Attaining access to Miller's archival material after Miller died in 1980, Honda uncovered additional facts about his life, incorporating various facts into his overarching view of the Christ-like themes in Miller's prose. In 1983 and 1987, Honda spent extensive time in the United States, visiting, among others, UCLA and the University of Texas, Austin, to gather Miller-related material. During these periods, he also visited Miller's long-time friend Emil White (1901-1989) in Big Sur. During their second meeting, they discussed Miller's elusive idea about writing Draco and the Ecliptic, a text Miller never started, but alluded to for decades. The idea for Draco, as Miller noted in a 1962 interview, was "to write a very slim work, explaining what I had been trying to do in writing all these books about my life. In other words, to forget what I had written and try once again to explain what I had hoped to do. In that way perhaps to give the significance of the work from the author's standpoint" (qtd. in Honda, In Quest 11). Honda pursued Miller's ideas concerning this text. In 1987, while chatting with Emil white, he recalls that when discussing

about the main points of Draco and the Ecliptic. [Emil] lit up and asked whether it was just my imagination talking. I replied by saying, 10\% imagination, $90 \%$ substantiated. He asked whether I'd ever met Miller. 'He hated academics,' I replied. 'Well, you should've met him,' Emil countered, at which I became happy just from hearing those words. ("Henrī Mirā" 68)

Dedicating his career to the search for meaning in Miller's literary world becomes evident in the title of Honda's 2003 English publication, In Quest of Draco and the Ecliptic. While his search did not compel him to communicate or meet Miller, the decades spent tracking down new biographical material has resulted in the Japanese publication of groundbreaking research on Miller.

\section{Conclusion}

Miller continued to embrace and utilize his popularity in Japan to its maximum potential, occasionally receiving some unwanted attention in the Japanese gossip magazines, but for the most part he enjoyed his affiliation with Japan and the Japanese individuals with whom he exchanged mail. Kubo, Ueno, Tobita, and Honda sought to better comprehend Miller, each with their own particular interest in the artist; in doing so they helped enhance Miller's name throughout Japan. The interest in Miller shown by these four Japanese men allows for a better understanding of the Japan-American literary affinity throughout the 1950 s into the 1980 s by revealing how these men sought to understand Miller's standpoint as an American. The intercultural differences between the men occasionally brought tension into their friendships, just as his failures to visit prevented Miller from seeing firsthand the realities of everyday life in Japan. Reading the letters from Miller, a certain level of obliviousness appears on his part when he conceptualizes Japan: it is clearly influenced by an artistic (painting and literature) and cinematic image of the society. On the other hand, while Miller is just a single sliver of the Japanese fascination with American culture, his influence in Japan should not be underestimated. Ueno's philosophical ideology that followed in Miller's footsteps, Tobita's efforts to succinctly translate Miller in a manner that would be 
accessible for everyday Japanese, and Honda's critical appraisal of Miller's literature from a biographical and religious perspective all illustrate the efforts to which Japanese individuals were willing to search for Miller. Kubo, likewise, believed that Miller's watercolors were an alternate window into the energetic forces emanating from Miller's art. All four Japanese men were searching for their own understanding of Miller, and in turn, they promoted Miller across Japan, advancing the cross-cultural communicability of Miller's art in Japan.

\section{BIBLIOGRAPHY}

Burtschell, Katrin. “Anaïs Nin, Henry Miller and Japan: An Endless Fascination.” A Cafe in Space: The Anaïs Nin Literary Journal, edited by Paul Herron, translated by Wolfgang Berger and Karl Orend, vol. 3, Sky Blue P, 2005, pp. 40-63.

Capouya, Emile. "Henry Miller." Salmagundi, vol. 1, no. 1, 1965, pp. 81-87.

Honda, Yasunori. "Henrī Mirā Kinen Toshokan Saihō" [The Henry Miller Memorial Library Revisited]. Nihon Henrī Mirā Kyōkai Kaihō [The Bulletin of The Henry Miller Society of Japan], vol. 2, 1987, pp. 64-70.

---. "Hōrō no Kaikisen to Ueno Shōri ni okeru Henrī Mirā gen taiken" [The Henry Miller Experience and Ueno Shōri's Tropiques En Voyageur]. Tropiques en Voyageur, by Shōri Ueno, 1972, pp. 541-45.

---. In Quest of Draco and the Ecliptic: Henry Miller's Interspatial Literature. Stroker P, 2003.

"Kakitsuzuketa koi no kunō no tegami: Henrī Mirā o kyōtan sa seta, Iwate ken no ningen dainamo" [The Continued Letters of Love's Struggles: The Man from Iwate who Astounded Henry Miller]. Shūkan Pureibōi [Weekly Playboy], no. 10, March 1970, pp. 28-33.

Keene, Donald. Dawn to the West: Japanese Literature of the Modern Era, Fiction. Holt, Rinehart and Winston, 1984.

Kiakis, Harry. Henry Miller in Pacific Palisades: Selections from a Journal. Nexus: The International Henry Miller Journal, 2017.

Koeppel, Gary. Henry Miller: The Centennial Print Collection. Coast Publishing, 2002.

Kubo, Sadajiro. Bijutsu no sekai: Henrī Mirā [The World of Art: Henry Miller]. Soubunsha, 1984.

---. “Gifted Painter: Henry Miller.” Itan No Bungō Wa Kaiga No Majutsu-Shidatta: Seitan 100 Nenkinen Henrī Mirā Kaiga-Ten" [The Heretic Writer That Was a Painting Magician: Henry Miller's 100th Anniversary Painting Exhibition]. Daito Art Printing, 1991, pp. 100-01.

---. "Toshinose no hibi [Thinking at the End of the Year: 1990]." Nihon Henrī Mirā kyōkai kaihō [The Bulletin of the Henry Miller Society of Japan], vol. 6, 1991, pp. 2-8.

Miller, Henry. Big Sur and the Oranges of Hieronymus Bosch. New Directions, 1957.

---. Book of Friends: A Tribute to Friends of Long Ago. Capra P, 1976.

---. The Colossus of Maroussi. New Directions, 1941. 
Rij, Jan van. Madame Butterfly: Japonisme, Puccini, and the Search for the Real Cho-Cho-San. Stone Bridge P, 2001.

Rikukawa, Hiroshi. "Henry Miller in Japan.” Henry Miller: A Book of Tributes 1931-1994, edited by Craig Peter Standish, Standish Books, 1994, pp. 497-500.

---. Nihon Ni Okeru Henrī Mirā Shoshi [A Bibliography of Henry Miller in Japan]. Hokuseido P, 1986.

Tobita, Shigeo. "80 Sai o mukaeru Henrī Mirā ichi: jiyū to mujaki no tatsujin ima nao kihaku otoroezu" [Henry Miller Turns 80: Master of Freedom and Innocence]. Yomiuri Shimbun, Yūkan [Evening Edition], 17 Dec. 1971, p. 7.

---. “Hakkan No Ji" [Preface]. Deruta: Henrī Mirā Anaisu Nin Rorensu Dareru Kenkyū Ronshū [Delta: Studies on Henry Miller, Anaïs Nin and Lawrence Durrell], vol. 1, 1998, pp. 3-4.

---. “Henrī Mirā kara no tegami” [Letters from Henry Miller]. Umi, vol. 12, no. 8, Aug. 1980, pp. 286-301.

"Tōhoku ni umoreta dai tetsuto: Henrī Mirā o hajime sekai no bunkabito ga 'kono hito koso Nihon no tetsugakumono' to zessan shita" [The Philosopher Hidden Away in the Tohoku Region: Henry Miller and Other World-Famous Cultured People Praise Him as Japan's Prominent Philosopher]. Shūkan josei jishin [Women's Weekly], no. 56, July 1981, pp. 58-64.

Tokuda, Toshiyuki. "Boku to, Kubo-san to, Henrī to, hippī” [Kubo Sadajiro, Henry Miller, Hippies and Me]. Nihon Henrī Mirā kyōkai kaihō [The Bulletin of the Henry Miller Society of Japan], vol. 8, 1993, pp. 5-24.

Ueno, Shōri. "Henrī Mirā ai to sei o kataru" [Henry Miller Speaks on Love and Sex]. Fujin kōron [Women's Public Opinion], vol. 63, no. 2, Feb. 1978, pp. 180-85.

---. Tropiques en Voyageur. Kodosha, 1972.

Usuda, Hiroshi. "Kubo Sadajirō to Henrī Mirā Kenkyūkai: Kenkyūkai No Setsuritsu Ni Itaru Made" [Kubo Sadajiro and the Henry Miller Society of Japan]. Deruta: Henrī Mirā Anaisu Nin Rorensu Dareru Kenkyū Ronshū [Delta: Studies on Henry Miller, Anaïs Nin and Lawrence Durrell], vol. 8, 2012, pp. 3-10.

\section{NOTES}

1. This research is supported by a Grants-in-Aid for Scientific Research from the Japan Society for the Promotion of Science (日本学術振興会) (\#18K12321).

2. Miller likely became aware in 1955 that his novel Sexus was being bootlegged in Japan after the Japanese government ordered police to raid bookstores, confiscating copies of Sexus.

3. Sections of Tropic of Cancer (1934) were initially translated in the privately published magazine Red and Black, no. 2 and no. 3, in 1946; the magazine only lasted three issues before being discontinued (Rikukawa, "Henry Miller" 498).

4. For all Japanese names, except Hoki Tokuda, I am following the Japanese preference of last name then first name.

5. Miller was somewhat aware that English versions of his books were being published in Japan. During the late 1950s, writing in Big Sur and the Oranges of Hieronymus Bosch about his banned books across the world, Miller noted that in Japan, the "Japanese version of [Sexus] has been suppressed but not the English, at least not yet" (Big Sur ix-x). As news about his publications filtered slowly out of Japan, Miller was not yet aware that his books were now deemed legally publishable in late 1955, in both English and Japanese editions. 
6. Yoshinaga, Hirohito (吉永博). Personal correspondence. 22 Dec. 2019.

7. For an in-depth look at the background of Miller's treatise on Mishima, see my article, "The Samurai and the Artist: Henry Miller's Reflections on the Death of Mishima."

8. Kubo to Miller, 2 Dec. 1956. Box 28, Folder 3, Henry Miller Papers (Collection 110). Department of Special Collections, Charles E. Young Research Library, University of California, Los Angeles. Hereafter: HMP, UCLA.

9. All translations are provided by my research assistant, Patrick Palmer.

10. Miller to Kubo. 23 Nov. 1956. Henry Miller Letters, Kubo Memorial Tourism and Culture Exchange Center (久保記念観光文化交流館). Hereafter: Kubo Memorial.

11. Miller to Kubo. 19 Feb. 1957. Kubo Memorial.

12. Miller to Kubo. 17 Apr. 1957. Kubo Memorial.

13. Kubo shipped the following books: Some Prefer Nettles (1929), by Tanizaki Junichirō (谷崎潤一 郎, 1886-1965); Rashōmon (1950), by Ryūnosuke Akutagawa (芥川龍之介, 1892-1927); The Sound of Waves (1954), by Mishima Yukio (三島由紀夫, 1925-1970); and, Snow Country (1948) by Kawabata Yasunari (川端康成, 1899-1972). All four of these novels were translated into English between 1955 and 1956. Kubo to Miller. 1 May 1957. Box 28, Folder 3, HMP, UCLA.

14. Miller to Kubo. 6 Dec. 1956. Kubo Memorial.

15. Miller to Kubo. 26 Aug. 1967. Kubo Memorial.

16. Kubo to Miller, 2 Dec. 1956. Box 28, Folder 3, HMP, UCLA.

17. After the first visit in 1967, Miller wrote to Kubo, who was then in New York City, expressing his sincere enjoyment about their in-person meeting, but also explaining that he was "sorry that you were unable to see my good paintings-I had given them away only a few days before you came." Miller to Kubo, 18 Mar. 1967. Kubo Memorial.

18. For more on Ueno Shōri, see my article: "Henry Miller and Ueno Shōri: A Transpacific Friendship." Faculty of Foreign Studies Bulletin, The University of Kitakyushu 149, (2019).

19. Ueno to Westwood Arts Association, carbon copy to Miller. 25 Mar. 1966. Box 59, Folder 8, HMP, UCLA.

20. Ueno to Miller. 16 Sept. 1977. Box 148, Folder 7, HMP, UCLA.

21. Ueno to Miller. 20 July 1966. Box 59, Folder 6, HMP, UCLA.

22. Ueno to Miller. 21 Aug. 1965. Box 59, Folder 6, HMP, UCLA.

23. Miller to Ueno. 23 May 1966. Personal collection of Ueno Shōri.

24. Miller to Ueno. 23 May 1966. Personal collection of Ueno Shōri.

25. Ueno to Miller. 18 June 1968. Box 59, Folder 11, HMP, UCLA.

26. Ueno to Miller. 30 May 1971. Box 74, Folder 2, HMP, UCLA.

27. Miller to Ueno. 23 May 1966. Personal collection of Ueno Shōri.

28. For Kai Ueno. 27 May 1969. Box 68, Folder 11, HMP, UCLA.

29. These dates are based on Tobita's letters at the Beinecke Rare Book and Manuscript Library, Yale University. Since the materials in the folder from Tobita seem chronologically complete, the dates I have attributed to their correspondence are likely inclusive. What is not yet known is if Miller replied after August 15, 1973.

30. Miller to Tobita, carbon copy. 12 Dec. 1971. Box 9, Folder 107, Henry Miller Papers (YCAL MSS 472). Beinecke Rare Book and Manuscript Library, Yale University. Hereafter: HMP, Yale.

31. Miller to Tobita. Mimeographed notes. N.d. Box 9, Folder 107, HMP, Yale. While translating western literature had become easier for the Japanese, likely still present were the difficulties that Donald Keene notes in Dawn to the West (1984): “The problems that Japanese encountered when translating European novels can hardly be exaggerated. The most common allusions to the people, places, or customs of the past had to be explained-or omitted" (69).

32. Roughly half of Miller's correspondence with Tobita has been located. Tobita mentions in his 1980 article that part of Miller's posts were typed and the other part was handwritten (Tobita, “Henrī Mirā" 287). 
33. Tobita also notes that he decided to leave out sections where Miller criticizes other Japanese individuals with whom he was corresponding, as well as his criticisms about Japanese publishers (Tobita, "Henrī Mirā" 288).

34. Tobita to Miller. 15 Aug. 1973. Box 9, Folder 107, HMP, Yale.

35. For more on Honda's personal reflections concerning his research with Miller, see my interview with Honda published in NEXUS: The International Henry Miller Journal Vol. 13, (2020).

36. Honda's five articles in English are: "In Quest of Tonia in Tropic of Cancer," in Stroker 67 (2000), recently republished in NEXUS: The International Henry Miller Journal, Vol. 12 (2020); "John Cowper Powys and Henry Miller: Another Pair of John the Baptist and Christ," in Stroker 68 (2000); "R. H. Blyth and Henry Miller," in Stroker 75 (2003); In Quest of Draco and the Ecliptic: Henry Miller's Interspatial Literature, Stroker Press (2003); and, "Georges Duhamel and Luis Bunuel in Tropic of Cancer," in NEXUS: The International Henry Miller Journal Vol. 2, (2005).

37. Ueno to J. Rives Childs. 12 Oct. 1970. Box 1. The Papers of J. Rives Childs, Accession \#9256-d, Special Collections Dept., University of Virginia Library, Charlottesville, Va.

38. Honda, Yasunori. Personal interview. 14 Sept. 2018.

39. Honda, Yasunori. Personal interview. 14 Sept. 2018.

\section{ABSTRACTS}

Nearly ten years before the United States Supreme Court ruling that made American author Henry Miller a household name, the Japanese courts had ruled that Miller's literature was art, and not pornographic. Consequently, beginning in the 1950s, Miller started shifting his attention more intently to the island nation of Japan. With his rising fame across Japan, various Japanese individuals sought to learn more about this controversial figure. By incorporating archival materials, field research, and interviews, this article focuses on four of these Japanese men who have had a calculable impact on Miller's reputation in Japan. Three them were in correspondence with Miller, another has become one of the foremost specialists in Henry Miller studies in the world. What is revealed herein is the decades-long personal relationship between Miller and Japan that has hitherto been unexplored by Miller scholars and biographers.

\section{INDEX}

Keywords: Japan, correspondence, transpacific, artist promotion, American-Japan relationship, watercolors, 20th-Century American literature, modernism, Japonsime

\section{AUTHOR}

\section{WAYNE E. ARNOLD}

Wayne E. Arnold is an Associate Professor of American Studies at the University of Kitakyushu. His research focus is Henry Miller and Japan. This topic has brought him to more than 28 archive libraries around the world in an effort to uncover Miller's relationship with Japan. Field research in Japan has uncovered letters from Miller to numerous Japanese individuals. Recent publications 
appear in NEXUS: The International Henry Miller Journal and DELTA: Studies on Henry Miller, Anaïs Nin and Lawrence Durrell, published by the Henry Miller Society of Japan. 